\title{
Hubungan Kebiasaan Mengkonsumsi Kopi dengan Tekanan Darah Pada Dewasa Muda
}

\author{
Difran Nobel Bistara1 ${ }^{1}$, Yanis Kartini ${ }^{2}$ \\ Fakultas Keperawatan dan Kebidanan Universitas Nahdlatul Ulama Surabaya ${ }^{1,2}$ \\ nobel@unusa.ac.id1,yanis@unusa.ac.id ${ }^{2}$
}

\begin{abstract}
ABSTRAK
Latar Belakang: Indonesia merupakan salah satu produsen kopi terbesar di dunia, tetapi memiliki nilai konsumsi kopi per kapita yang masih relatif rendah yaitu sekitar 70.000 ton/tahun atau 0,5 $\mathrm{kg} /$ orang/tahun. Kopi sering dikaitkan dengan sejumlah faktor risiko penyakit jantung koroner, termasuk meningkatkan tekanan darah dan kadar kolesterol darah karena kopi mempunyai kandungan kalium, polifenol, dan kafein. Kafein memiliki sifat meningkatkan tekanan darah, sedangkan kalium dan Polifenol memiliki sifat menurunkan tekanan darah.

Tujuan: Penelitian ini bertujuan untuk mengidentifikasi hubungan antara kebiasaan mengkonsumsi kopi dengan tekanan darah pada dewasa muda.

Metode: Jenis penelitian yang digunakan dalam penelitian ini adalah kolerasional dengan desain penelitian cross sectional. Variabel independennya adalah kebiasaan mengkonsumsi kopi dan variabel dependennya adalah tekanan darah. Pengambilan sampel dilakukan di Demak Jaya kelurahan Tembok Dukuh kecamatan Bubutan, Surabaya pada bulan Agustus-September 2017. Besar sampel sejumlah 40 responden yang diambil dengan teknik purposive sampling. Data yang diperoleh dikumpulkan dengan menggunakan lembar kuesioner dan observasi. Klaifikasi skala pengumpulan data ordinal dengan uji statistik yang digunakan pada penelitian ini adalah korelasi Spearman Rank.

Hasil: Hasil uji statistik Spearman Rho p=0.465 (=0.05), menunjukkan bahwa H1 ditolak, sehingga dapat disimpulkan tidak ada hubungan kebiasaan mengkonsumsi kopi dengan tekanan darah pada dewasa muda di Demak Jaya kelurahan Tembok Dukuh kecamatan Bubutan, surabaya.

Kesimpulan: Peningkatan tekanan darah juga dapat disebabkan oleh faktor lain seperti stasus ekonomi, kegemukan, psikososial (stres), merokok, aktivitas fisik, konsumsi alkohol berlebih dan konsumsi garam.
\end{abstract}

Kata Kunci: kebiasaan mengkonsumsi kopi; tekanan darah.

\begin{abstract}
Background: Indonesia is one of the largest coffee producer in the world, but has a value of coffee per capita consumption is still relatively low at around 70,000 tonnes / year or $0.5 \mathrm{~kg} /$ person / year. Coffee is often associated with a number of risk factors for coronary heart disease, including increased blood pressure and blood cholesterol levels because coffee has potassium, polyphenols, and caffeine. Caffeine has properties increase blood pressure, whereas potassium and polyphenols have blood pressure lowering properties.

Objective: This study aimed to identify the relationship between habitual coffee consumption and blood pressure in young adults.

Methods: This type of research used in this study is correlation with cross sectional study design. The independent variable was the coffee consumption habits and the dependent variable is blood pressure. Sampling was conducted in Demak Jaya Tembok Dukuh, Bubutan, Surabaya in August-September 2017. The sample number of 40 respondents taken by using purposive sampling. The data obtained were collected by using questionnaire and observation. Classification of data collection ordinal scale with statistical test used in this study using Spearman Rank correlation.

Results: Spearman Rho $p=0465(=0,05)$, showed that H1 is rejected, so that it can be concluded there is no relationship of coffee consumption habits with blood pressure in young adults in Demak Jaya Tembok Dukuh, Bubutan, Surabaya.

Conclusion: Increased blood pressure can also be caused by other factors such as economic stasus, obesity, psychosocial (stress), smoking, physical inactivity, excessive alcohol consumption and the consumption of salt.
\end{abstract}

Keywords: eating habits coffee; high blood pressure. 


\section{PENDAHULUAN}

Kopi menjadi salah satu minuman paling popular dan digemari semua kalangan, salah satunya pada anak muda dewasa muda. Disisi lain kopi sering dikaitkan dengan sejumlah faktor risiko penyakit jantung koroner, termasuk meningkatkan tekanan darah dan kadar kolesterol darah karena kopi mempunyai kandungan polifenol, kalium dan kafein. Kafein dikatakan sebagai penyebab berbagai penyakit khususnya hipertensi, tapi masih banyak kalangan seperti dewasa muda yang tidak mengetahui hal tersebut bahkan walaupun mereka sudah mengetahui hal tersebut mereka akan tetap menganggap minuman tersebut adalah kewajiban minuman yang harus dinikmati setiap hari (Zhang, 2011).

Data di RSUD Bangkalan tahun 2011 selama 3 bulan tekahir, pasien hipertensi yang menjalani rawat inap rata-rata 20 orang. Konsumsi kopi juga diproyeksikan meningkat sebesar $0,4 \%$ per tahun di tahun 2010 yaitu 6,9 juta ton dari tahun 1998 -2000 yaitu 6,7 juta ton. Sistem sirkulasi manusia memiliki faktor yang penting yaitu tekanan darah. Homeostatis di dalam tubuh dipengaruhi oleh penurunan atau peningkatan tekanan darah. Alirah darah yang menetap memerlukan tekanan darah untuk mengalirnya darah di dalam sistem vena dan kapiler, arteriola, dan arteri (Ningrat, 2012).

Gangguan sistem transportasi karbondioksida, oksigen dan hasil metabolism lainnya akan terjadi jika sirkulasi darah tidak memadai. Tekanan darah tinggi dipengaruhi oleh beberapa faktor, yaitu faktor lingkungan yang meliputi alkohol, stress, merokok, obesitas, konsumsi garam, kafein seperti mengkonsumsi kopi serta ciri individu seperti faktor genetik, suku, jenis kelamin, dan usia. Senyawa kafein pada seseorang yang minum kopi bisa menyebabkan tekanan darah meningkat tajam sehingga sangat berbahaya bagi penderita hipertensi (Hamer, 2006).

Kafein di dalam tubuh manusia bekerja dengan cara memicu produksi hormon adrenalin yang berasal dari reseptor adinosa di dalam sel saraf yang mengakibatkan peningkatan tekanan darah, pengaruh dari konsumsi kafein dapat dirasakan dalam waktu 5-30 menit dan bertahan hingga 12 jam. Efeknya akan berlanjut dalam darah selama sekitar 12 jam. Konsumsi satu atau dua cangkir kopi dalam sehari dapat membuat seseorang merasa lebih terjaga dan waspada untuk sementara (Indriyani, 2009).

Peningkatan resistensi pembuluh darah tepi dan vasokonstriksi di sebabkan oleh kafein yang memiliki sifat antagonis endogenus adenosin. Peningkatan tekanan darah dipengaruhi oleh dosis kafein yang dikonsumsi. Dosis kecil kafein yang biasa dikonsumsi oleh Seseorang mempunyai adaptasi/efek yang rendah (Wahyuni, 2013).

Pencegahan hipertensi dapat dilakukan dengan berbagai cara. Adapun kunci utamanya adalah dengan merubah pola makan dan membiasakan diri melakukan olahraga. Gizi seimbang diharapkan dikonsumsi Setiap orang dengan cara mengurangi makanan yang mengandung lemak jenuh dan memperbanyak konsumsi sayuran dan buah. Selain itu, pembatasan konsumsi garam sebaiknya dibatasi sejumlah 5 gram per hari, mengurangi penggunaan alkohol akan mencegah terhambatnya aliran darah, dan mengurangi kebiasaan merokok akan mencegah rusaknya lapisan dinding arteri (Ningrat, 2012).

Setiap individu diharapkan melakukan aktivitas fisik/olahraga sebaiknya 30 menit perhari untuk mencegah terjadinya hipertensi. Pencegahan hipertensi juga dapat dilakukan dengan pengaturan stres dengan baik, misalnya dengan kontak positif, yoga dan juga meditasi (Widiyani, 2013). Tujuan penelitian ini adalah untuk mengidentifikasi kebiasaan mengkonsumsi kopi dengan tekanan darah pada dewasa muda di Demak Jaya, Kelurahan Tembok Dukuh, Kecamatan Bubutan, Surabaya.

\section{METODE}

Jenis penelitian ini adalah penelitian korelasional dengan desain penelitian cross sectional. Populasinya adalah seluruh dewasa muda yang memiliki kebiasan mengkonsumsi kopi. Sampelnya adalah sebagian dewasa muda yang memiliki kebiasan mengkonsumsi kopi di Demak Jaya, Kel. Tembok Dukuh, Kec. Bubutan, Surabaya. Variabel independen dalam penelitian ini adalah kebiasaan mengkonsumsi kopi, variabel dependen adalah tekanan darah. Data dikumpulkan dengan lembar kuesioner, analisa data dengan uji Spearman rank test (Nursalam, 2013; Hidayat, 2009). 
HASIL

Data Umum

Data umum adalah karakteristik responden mengkonsumsi kopi dengan tekanan darah pada dewasa Muda dari Demak Jaya, Kelurahan Tembok Dukuh, Kecamatan Bubutan, Surabaya, yang meliputi umur, jenis kelamin, dan pekerjaan.

1. Karakteristik Responden Berdasarkan Umur, Jenis Kelamin dan Pekerjaan.

Tabel 1 Karakteristik Responden Berdasarkan Umur, Jenis kelamin, dan Pekerjaan Di Demak Jaya Kelurahan Tembok Dukuh Kecamatan Bubutan, Surabaya pada Bulan AgustusSeptember 2017.

\begin{tabular}{|c|c|c|c|}
\hline No & Karakteristik & $\mathbf{N}$ & $\%$ \\
\hline \multicolumn{4}{|c|}{ Umur } \\
\hline 1. & $26-30$ & 31 & $77.5 \%$ \\
\hline \multirow[t]{2}{*}{2.} & $31-35$ & 9 & $22.5 \%$ \\
\hline & Jumlah & 40 & $100 \%$ \\
\hline \multicolumn{4}{|c|}{ Jenis Kelamin } \\
\hline 1. & Laki-laki & 35 & $87.5 \%$ \\
\hline \multirow[t]{2}{*}{2.} & Perempuan & 3 & $12.5 \%$ \\
\hline & Jumlah & 40 & $100 \%$ \\
\hline \multicolumn{4}{|c|}{ Pekerjaan } \\
\hline 1. & IRT & 3 & $7.5 \%$ \\
\hline 2. & Wiraswasta & 12 & $30 \%$ \\
\hline \multirow[t]{3}{*}{3.} & PNS & 6 & $15 \%$ \\
\hline & Lain-lain & 19 & $47.5 \%$ \\
\hline & Jumlah & 40 & $100 \%$ \\
\hline
\end{tabular}

Berdasarkan Tabel 1 menunjukkan bahwa sebagian besar responden di Demak Jaya, Kelurahan Tembok Dukuh, Kecamatan Bubutan, Surabaya, yaitu berumur 26-30 tahun berjumlah 31 (77.5\%). Sebagian besar responden berjenis kelamin laki-laki berjumlah 35 responden (87.5\%). Sebagian besar responden bekerja sebagai buruh, pengangguran (tidak bekerja), kerja serabutan berjumlah 19 responden (47.5\%)

\section{Data Khusus}

Tabel 2 Distribusi Frekuensi Responden

Berdasarkan Tekanan Darah Di Demak Jaya

Kelurahan Tembok Dukuh Kecamatan Bubutan, Surabaya pada Bulan Agustus-September 2017.

\begin{tabular}{llll}
\hline No & Tekanan Darah & N & $\%$ \\
\hline 1. & Normal & 32 & $80 \%$ \\
& Sistole 120 & & \\
& mmHg & & \\
& Diastole 80 & & \\
& mmHg & & \\
\hline
\end{tabular}

Tabel 2 (lanjutan) Distribusi Frekuensi Responden Berdasarkan Tekanan Darah Di Demak Jaya Kelurahan Tembok Dukuh Kecamatan Bubutan, Surabaya pada Bulan Agustus-September 2017.

\begin{tabular}{|c|c|c|c|c|}
\hline No & \multicolumn{2}{|c|}{ Tekanan Darah } & $\mathbf{N}$ & $\%$ \\
\hline \multirow[t]{6}{*}{2.} & \multicolumn{2}{|c|}{ Hipertensi } & 7 & $17.5 \%$ \\
\hline & \multicolumn{2}{|c|}{ Stadium 1} & & \\
\hline & Sistole & 121-159 & & \\
\hline & $\mathrm{mmHg}$ & & & \\
\hline & Distole & $81-99$ & & \\
\hline & $\mathrm{mmHg}$ & & & \\
\hline \multirow[t]{7}{*}{3.} & \multicolumn{2}{|c|}{ Hipertensi } & 1 & $2.5 \%$ \\
\hline & \multicolumn{2}{|l|}{ Stadium 2} & & \\
\hline & Sistole & 160 & & \\
\hline & $\mathrm{mmHg}$ & & & \\
\hline & Distole & 100 & & \\
\hline & $\mathrm{mmHg}$ & & & \\
\hline & Jumlah & & $40 \%$ & $100 \%$ \\
\hline
\end{tabular}

Berdasarkan Tabel 2 menunjukkan bahwa hampir sebagian besar responden Tekanan Darah Normal berjumlah 32 responden $(80 \%)$.

Tabel 3 Distribusi Frekuensi Responden Berdasarkan Kebiasaan Mengkonsumsi Kopi Di

Demak Jaya Kelurahan Tembok Dukuh

Kecamatan Bubutan, Surabaya pada Bulan Agustus-September 2017.

\begin{tabular}{|c|c|c|c|}
\hline No & $\begin{array}{l}\text { Kebiasaan } \\
\text { Mengkonsumsi } \\
\text { Kopi }\end{array}$ & $\mathbf{N}$ & $\%$ \\
\hline 1 & Rendah & 10 & $25 \%$ \\
\hline 2 & Moderat & 29 & $72.5 \%$ \\
\hline 3 & Tinggi & 1 & 2.5 \\
\hline & Jumlah & 40 & $100 \%$ \\
\hline
\end{tabular}
bahwa distribusi frekuensi responden berdasarkan variabel mengkonsumsi kopi sebagian besar responden memiliki kebiasaan minum kopi dengan kriteria moderat dengan jumlah 29 responden (72.5\%).

Tabel 4 Uji Stastistik Hubungan Kebiasaan Mengkonsumsi Kopi dengan Tekanan Darah Di Demak Jaya Kelurahan Tembok Dukuh Kecamatan Bubutan, Surabaya pada Bulan

\begin{tabular}{lllll}
\hline Kebiasaan & \multicolumn{3}{c}{ Tekanan Darah } & \multirow{2}{*}{ TOTA } \\
\cline { 2 - 4 } $\begin{array}{l}\text { Mengkons } \\
\text { umsi Kopi }\end{array}$ & $\begin{array}{l}\text { Norm } \\
\text { al }\end{array}$ & $\begin{array}{l}\text { Hiperten } \\
\text { si Stad-1 }\end{array}$ & $\begin{array}{l}\text { Hiperten } \\
\text { si Stad-2 }\end{array}$ & L \\
\hline Tinggi & 0 & 0 & $1(2.5 \%)$ & 1 \\
Moderat & 32 & 0 & 0 & 32 \\
& $(80 \%)$ & & & \\
Rendah & 0 & $7(17.5 \%)$ & 0 & 7 \\
Total & 32 & 7 & 1 & 40 \\
Hasil Uji Spearman $\mathrm{p}=0,465$ & & \\
Correlation Coefficient $\mathrm{r}=0,119$ & & \\
\hline
\end{tabular}

Agustus-September 2017. 
Berdasarkan Tabel 4 Hasil Uji Spearman menunjukkan tingkat signifikasi $\mathrm{p}=0,465$ dengan $=0,05$ sehingga $\mathrm{H}_{0}$ diterima yaitu tidak terdapat hubungan kebiasaan mengkonsumsi kopi dengan tekanan darah pada dewasa awal dengan Correlation Coefficient $r=0,119$. Hal ini menunjukkan bahwa antar variabel tidak terdapat hubungan yang kuat.

\section{PEMBAHASAN}

Hasil penelitian yang dilakukan pada bulan Agustus-September 2017 didapatkan hasil bahwa sebagian besar responden yaitu berumur 26-30 tahun berjumlah 31 (77.5\%). Risiko kenaikan tekanan darah meningkat seiring dengan bertambahnya usia (Whitney \& Rolfes, 2008). Pathogenesis hipetensi terjadi seiring dengan adanya peningkatan usia hal ini akibat aterosklerosis yang menunjang peningkatan perifer total dan selanjutnya tahanan pembuluh darah ini meningkatkan afterload bagi fungsi jantung, sehingga jantung harus bekerja lebih berat sehingga mengakibatkan terjadinya hipertensi.

Hasil peneitian juga menunjukkan dari 40 responden yang diteliti sebagian besar responden memiliki kebiasaan asupan kopi dengan kriteria moderat: $200 \mathrm{mg}-300 \mathrm{mg}$ perhari (contoh : 4 cangkir kopi sehari) dengan jumlah 29 responden (72.5\%), dalam hal ini kebiasaan tersebut tidak akan menyebabkan kerusakan jangka panjang.

Berdasarkan penelitian yang dilakukan oleh Martiani (2012) kebiasaan minum kopi $>4$ cangkir perhari dapat mentoleransi efek kafein pada kopi, sehingga tidak mengakibatkan peningkatan tekanan darah. Paparan kafein pada kopi secara hemodinamik dan hormonal yang terjadi terus menerus dapat ditoleransi oleh tubuh yang memiliki regulasi hormon kompleks yang bertugas menjaga tekanan darah tetap stabil.

Kopi mengandung kalium dan polifenol yang dapat menurunkan tekanan darah, selain memiliki kandungan yang dapat meningkatkan tekanan darah. Kopi instan merupakan kopi yang dikonsumsi oleh responden. Polifenol (antioksidan) terkandung dalam Kopi instan yang terdapat serat larut air yang tinggi. Polifenol menghambat terjadinya atherogenesis dan memperbaiki fungsi vaskuler. Selain polifenol, kandungan yang cukup tinggi dalam kopi diketahui adalah kalium. Kalium menghambat pelepasan renin yang berfungsi menurunkan tekanan darah sistolik dan diastolik sehingga terjadi peningkatan eksresi air dan natrium. Pelepasan renin tersebut menyebabkan terjadinya penurunan curah jantung, tekanan perifer dan volume plasma, sehingga tekanan darah akan turun (Indriyani, 2009).

Polifenol dan kalium dapat menyeimbangkan efek kafein. Adapun upaya individu dalam mengurangi kebiasaan minum kopi yaitu dengan berolahraga secara teratur dan menggantikan kebiasaan minum kopi dengan minuman lain. Jika kebiasaan minum kopi terus dilakukan tidak menutup kemungkinan maka akan memicu terjadinya hipertensi atau peningkatan tekanan darah dikarenakan salah satu zat dari kopi dapat memicu peningakatan tekanan darah dalam tubuh yaitu kafein. Kafein dapat membuat tekanan darah meningkat dan jantung berdebar (Purnomo, 2009).

Hasil penelitian terkait tekanan darah menunjukkan bahwa mayoritas responden mengalami tekanan darah normal yaitu 32 orang $(80 \%)$, responden yang mengalami hipertensi stadium 1 yaitu 7 orang (17.5\%) dan yang mengalami hipertensi stadium 2 yaitu 1 orang $(2.5 \%)$. Hal ini menunjukkan bahwa ketidakstabilan tekanan darah tidak disebabkan oleh faktor kebiasaan minum kopi saja. Faktor usia juga dapat mempengaruhi tekanan darah, resiko terkena hipertensi pada saat memasuki masa pra lansia dengan bertambahnya usia, resiko menjadi lebih besar sehingga prevalensi kejadian hipertensi dikalangan usia lanjut cukup tinggi sekitar $40 \%$ dengan kematian lebih banyak terjadi pada usia diatas 65 tahun (Wahyuni, 2013).

Tingginya hipertensi bertambah seiring dengan bertambahnya usia hal ini disebabkan oleh perubahan struktur pada pembuluh darah besar, yang menyebabkan penyempitan lumen dan kekakuan dinding pembuluh darah dan mengakibatkan terjadinya peningkatan tekanan darah sistolik. Pada usia muda cenderung memiliki koping yang baik terhadap tekanan darah karena mereka dapat mengontrol dengan melakukan banyak aktivitas seperti olahraga secara teratur, menkonsumsi kopi tidak berlebihan, menggantikan kebiasaan minum kopi dengan minuman yang lain, dll. 
Jenis kelamin juga berpengaruh pada kebiasaan minum kopi, rata-rata responden yang memiliki kebiasaan minum kopi mayoritas berjenis kelamin laki-laki karena sebagian besar responden memiliki pekerjaan sebagai buruh, dan kerja serabutan, serta ada juga responden pengangguran (tidak bekerja), dalam hal ini mereka memiliki waktu luang yang lebih banyak dibandingkan responden yang memiliki perkerjaan lainnya seperti PNS dan Wiraswasta sehingga memiliki kebiasaan mengkonsumsi kopi lebih tinggi (Ningrat, 2012).

Hasil penelitian berdasarkan uji statistik hubungan kebiasaan mengkonsumsi kopi dengan tekanan darah dewasa muda menunjukkan bahwa kebiasaan mengkonsumsi kopi moderat dengan karakteristik tekanan darah normal yaitu 32 orang $(80 \%)$, kebiasaan mengkonsumsi kopi rendah dengan karakteristik tekanan darah hipertensi stadium 1 yaitu 7 orang (17.5\%) dan kebiasaan mengkonsumsi tinggi dengan karakteristik tekanan darah hipertensi stadium 2 yaitu 1 orang (2.5\%).

Hasil dari uji statistik menyimpulkan tidak ada hubungan antara kebiasaan mengkonsumsi kopi dengan tekanan darah pada dewasa muda dimana $\mathrm{p}=0,465$ dengan $=0,05$, Hal ini membuktikan bahwa responden yang memiliki kebiasaan minum kopi tidak mempengaruhi tekanan darah secara berlebihan tetapi menyebabkan naiknya tekanan darah dalam waktu singkat untuk kemudian kembali normal (Notoatmodjo, 2007).

Hasil tersebut menunjukkan tidak ada hubungan antara kebiasaan mengkonsumsi kopi dengan tekanan darah pada dewasa muda karena setiap responden mempunyai kebiasaan mengkonsumsi kopi berbeda dan ternyata masih banyak responden yang mempunyai tekanan darah normal karena 4 cangkir kopi tidak akan menyebabkan perubahan tekanan darah (Purnomo, 2009).

Hal ini juga selaras dengan penelitian yang dilakukan oleh Uiterwaal, et. al (2007) bahwa peminum kopi berat ( $>6$ cangkir per hari) memiliki risiko hipertensi lebih rendah daripada peminum kopi ringan (1-3 cangkir per hari). Akan tetapi hal ini bertentangan dengan peneltian Klag et. al (2002) bahwa risiko hipertensi pada peminum kopi 1-2 cangkir per hari lebih tinggi jika dibandingkan dengan bukan peminum kopi.

\section{PENUTUP}

\section{A. Kesimpulan}

Penelitian tentang hubungan antara kebiasaan mengkonsumsi kopi dengan tekanan darah pada dewasa muda, sebagian besar memiliki kebiasaan mengkonsumsi kopi moderat dengan jumlah responden 29 (72\%). Responden dengan tekanan darah normal dengan jumlah responden 32 (80\%). Tidak ditemukan responden mengkonsumsi kopi yang mempengaruhi tekanan darah. Jadi dapat disimpulkan bahwa tidak ada hubungan antara mengkonsumsi kopi dengan tekanan darah pada dewasa awal. Keterbatasan penelitian ini karena tidak terdapatnya pengukuran kadar kafein yang terkandung dari kopi yang dikonsumsi oleh responden sehingga hasil yang didapatkan kopi tidak mempengaruhi tekanan darah.

\section{B. Saran}

1. Bagi Peneliti Selanjutnya

Saran yang dapat diberikan kepada peneliti selanjutnya adalah lebih meperbanyak teori-teori yang diperoleh dari berbagai sumber terbaru dan mengukur kadar kafein untuk data lebih lengkap.

2. Bagi Instansi

Dapat dijadikan wacana menambah ilmu pengetahuan, aturan minum kopi serta takaran minum kopi yang cukup.

3. Bagi Masyarakat

Dapat dijadikan informasi oleh masyarakat tentang perlunya mengurangi kebiasaan mengkonsumsi kopi yang sangat diperlukan dalam memelihara kesehatan secara umum.

\section{DAFTAR PUSTAKA}

Hamer, M. (2006). Coffe and Health: Explaining Conflicting Results in Hypertension. Journal of Human Hypertension, 20, 909-912

Hidayat, Aziz Alimul. (2009). Metode Penelitian Keperawatan dan Teknik Analisa Data. Jakarta : Salemba Medika

Indriyani Widayani. (2009). Deteksi Dini Kolestrol, Hipertensi, dan Stroke. Millestone

Klag, M.J., et. al. (2002) Coffe Intake and Risk of Hypertension. Arch Intern Med, 162, 657-662

Martiani, Ayu. (2012). Faktor Resiko Hipertensi Ditinjau Dari Kebiasaan 
Minum Kopi. Semarang: Fakultas Kedokteran UNDIP

Ningrat, Ranny Wahyu, dan Budi Sentosa. (2012). Pemilihan Diet Nutrien Bagi Penderita Hipertensi Menggunakan Metode Kalsifikasi Decisieon Tree (RSUD Syarifah Ambami Rato Ebu Bangkalan). Surabaya: ITS

Nursalam. (2013). Metode Penelitian Ilmu Keperawatan Edisi 3. Salemba Medika

Notoatmodjo, Soekidjo. (2007). Pendidikan dan Perilaku Kesehatan. Jakarta : Rineka Cipta

Purnomo, Heru. (2009). Pencegahan dan Pengobatan yang Penyakit Paling Mematikan. Jakarta : Buana Pustaka
Wahyuni, Tri. (2013). Hubungan Konsumsi Kopi Dengan Tekanan Darah Pada Pasien Rawat Jalan Puskesmas Bogor Tengah. Bogor: Departemen Gizi Masyarakat Fakultas Ekologi Manusia

Whitney, E., Rolfes, S.R. (2008). Hypertension: Understanding Nutrition 1th Edition. Belmont: Wadsworth, 633-634

Uiterwaal, C., et. al. (2007). Coffee Intake and Incidence of Hypertension. Am J Clin Nutr, 85, 718-23

Zhang, Z., et. al. (2011). Habitual Coffee Consumption and Risk of Hypertension: A Systematic Revies and Meta-analysis of Prospective Observational Studies. Am J Clin Nutr 